\title{
TREATED RESIDENTIAL GREYWATER AND ITS EFFECT ON SHOOT DRY MATTER AND NUTRIENT UPTAKE OF MAIZE (ZEA MAYS)
}

\author{
MEHRUNISA MEMON ${ }^{1}$, ABDUL MAJID NAREJO ${ }^{1}$, FAYYAZ ALI MEMON ${ }^{2}$, \\ RASOOL BUX MAHAR ${ }^{3,4}$ AND HIDAYATULLAH KAKAR ${ }^{1}$
}

\author{
${ }^{1}$ Sindh Agriculture University, Faculty of Crop Production, Department of Soil Science, Tandojam, Sindh, Pakistan \\ ${ }^{2}$ Centre for Water Systems, College of Engineering, Mathematics and Physical Science, University of Exeter, Exeter, EX4 \\ 4QF, United kingdom; ${ }^{3}$ Mehran University of Engineering and Technology, US-Pakistan; \\ ${ }^{4}$ Center for Advanced Studies in Water, Jamshoro, Sindh, Pakistan \\ *Correspondence author's email: nisamemon@gmail.com
}

\begin{abstract}
Shortage of freshwater resources and limited fertilizer usage due to cost related issues in agriculture are the basic limiting factors in food production. This study evaluated the effect of greywater application on shoot dry mater and uptake of maize crop. The experiment included five treatments canal water, untreated greywater and treated greywater through reed bed technology using Cyperus iria, Phragmites karka and Typha elephantina, arranged in a randomized complete block design. All the treatments received a basal doze of NPK fertilizer. The soil used in the experiment was silty clay in texture with $55 \%$ clay, $\mathrm{pH}-7.70$, EC - $1.07 \mathrm{dS} \mathrm{m}{ }^{-1}, \mathrm{CaCO}_{3}-12.50 \%$ organic matter $-0.17 \%, \mathrm{NO}_{3}-\mathrm{N}-4.60 \mathrm{mg} \mathrm{kg}^{-1}, \mathrm{NH}_{4}-\mathrm{N}-1.68 \mathrm{mg} \mathrm{kg}^{-1}$, ammonium bicarbonate diethylene triamine penta acetic acid (AB-DTPA) extractable $\mathrm{P}$ and $\mathrm{K}$ as 0.18 and $270 \mathrm{mg} \mathrm{kg}^{-1}$, respectively. The treated greywater had a highly significant effect on shoot dry matter and $\mathrm{N}, \mathrm{P}$ and $\mathrm{K}$ uptake in maize. The highest contents were found in treatments applied with greywater, treated under reed bed technology using Cyperus iria and the lowest in canal water applied treatments. Part of applied fertilizer was supplemented through greywater application.
\end{abstract}

Key words: Greywater application, Maize, Nitrogen, Phosphorus, Potassium.

\section{Introduction}

Inadequate use of chemical fertilizers due to cost related issues, coupled with poor fertility of soils and particularly the scarcity of freshwater resources are big threats to agriculture production (Maqbool et al., 2019). The huge quantities of wastewater generated from an over populated country like Pakistan is another concern to environment and a hazard to human health. According to Pakistan Economic Survey (Anon., 2016), the main sources of wastewater generation in Pakistan are rural residential (48\%) and urban (25\%), while the remaining $16 \%, 6 \%$, and $5 \%$, respectively are agriculture, industry and commercial based.

Wastewater quality is based on the type and its source. Chemical constituents and heavy metal load is way too high in industrial and municipal wastewater over domestic one (Jenssen \& Vrale, 2004). Greywater is the domestic wastewater excluding toilet waste. On an average $65 \%$ of domestic wastewater is reported to be greywater (Eriksson et al., 2003; Friedler and Hadari, 2006). The nutrient contents (i.e. NPK) and microorganisms hazardous to human health are generally low in treated greywater (Jenssen \& Vrale, 2004) and therefore, the wastewater causing environmental pollution can turn into a valuable source of chemical fertilizer in agriculture. Treated greywater use on agricultural lands is a common practice in many countries of the world. It is successfully used on cotton, wheat, maize, sunflower, different vegetables (i.e. okra, tomatoes, spinach, beans, etc.) including fruit trees (Oliver \& Hossain, 2016; Fagan, 2015; Mzini \& Winter, 2015; Al-Hamaiedeh \& Bino, 2010; Rusan et al., 2007 and Day et al., 1981). Generally, these experiments reported an increased growth, leaf nutrient contents with relevant uptake and the productivity due to presence of $\mathrm{N}, \mathrm{P}$ and $\mathrm{K}$ contents in greywater. These studies show either no or low adverse effects on plants. Long term experiments may show salt (Zuma et al., 2009) or heavy metal i.e. $\mathrm{Pb}$ and $\mathrm{Ni}$ (Rusan et al., 2007) accumulation in soils or high nutrient uptake as in case of tomato (Misra et al., 2009). This is due to high contents of nutrients in greywater. This can be best avoided by diluting the greywater before its application (Day et al., 1981).

A small number of local studies have highlighted the treatment of greywater (Memon et al., 2017; Hayder et al., 2015; Mustafa, 2013; Iram et al., 2012 and Aslam et al., 2007) however its usage in crops is not a common practice in Pakistan agriculture. The main objective of this study was to introduce and assess treated greywater application in agriculture with maize as a test crop. The details of greywater treatments have been given elsewhere (Memon et al., 2017).

\section{Materials and Methods}

This study relates to the use of greywater in agriculture, rather than its treatment, which has been detailed in a separate study (Memon et al., 2017). The greywater used in this experiment was collected from reed bed units planted with Cyperus iria (sedge grass), Phragmites karka (reed grass) and Typha elephantina (reed mace). These units were constructed at Sindh Agriculture University Residential Area, Tandojam, Sindh Pakistan. Greywater from ten houses was treated into these units by discharging $90 \mathrm{~L}$ per day' thrice a day at an equal interval time. Treated greywater from each of the three units was collected into $1000 \mathrm{ml}$ autoclaved bottles, every third day around 8.00 in the morning. Samples were packed on ice in insulated coolers and transported to the laboratory. 
Bulk surface soil $(0-15 \mathrm{~cm})$ was collected from Latif Experimental Farm, Sindh Agriculture University Tandojam, located in the southern $\left(25^{\circ} 25^{\prime} 35.60^{\prime \prime} \mathrm{N}\right.$, $68^{\circ} 32^{\prime} 35.76^{\prime \prime} \mathrm{E}$, elevation $25 \mathrm{~m}$ ) part of Pakistan. Soil was dried in shade, debris were removed and ground and passed through $2 \mathrm{~mm}$ sieve. A small portion of soil was reserved for analysis. A $5 \mathrm{~kg}$ quantity was placed in each 15 plastic pots to represent five treatments i.e. canal water, untreated greywater, and treated greywater from reed beds planted with each Cyperus iria, Phragmites karka and Typha elephantine. The experiment was arranged in a randomized complete block design with three replications. The crop received half $\mathrm{N}$, and full $\mathrm{P}$ and $\mathrm{K}$ of the recommended rate (150-80-60 kg N- $\mathrm{P}_{2} \mathrm{O}_{5}-\mathrm{K}_{2} \mathrm{O} \mathrm{ha}^{-1}$ ) during soil preparation, while the other half of $\mathrm{N}$ was applied after 30 days of sowing. Two maize seeds of Akbar variety were sown in the center and in cross position of each pot, which after germination were thinned to four plants. All the pots were irrigated as per treatment details and followed the recommended irrigation requirement and agronomic practices. To provide similar environment to all the plants, pots were rotated every third day.

Maize plants were harvested after six weeks. Shoot dry matter yield was recorded, and the plants were dried, ground and preserved for nutrient analysis. Canal water and spentwash samples were analyzed for electrical conductivity, $\mathrm{pH}$, biological oxygen demand (BOD), total suspended solids (TSS), total dissolved solids (TDS), $\mathrm{NH}_{4}$ $\mathrm{N}, \mathrm{NO}_{3}-\mathrm{N}$, and total $\mathrm{P}$ and $\mathrm{K}$ as described under AWWA, APHA and WEF (1998). Soil samples in addition to electrical conductivity, $\mathrm{pH}, \mathrm{NH}_{4}-\mathrm{N}$ and $\mathrm{NO}_{3}-\mathrm{N}$ were tested for texture, $\mathrm{CaCO}_{3}$, organic matter content and available $\mathrm{P}$ and $\mathrm{K}$ (Estefan et al., 2013). While, plant samples were tested for total $\mathrm{N}, \mathrm{P}$ and $\mathrm{K}$ and respective nutrient uptakes were calculated as a product of shoot dry matter and relevant nutrient concentration (Memon et al., 2017). All the data was subjected to analysis of variance and those significant were used for comparison of means $\left(\mathrm{LSD}_{0.05}\right)$ using Statistix 8.1.

\section{Results}

Soil and greywater characteristics: The experimental soil was silty clay in texture with $\mathrm{pH}-7.70$, electrical conductivity - $1.07 \mathrm{dS} \mathrm{m}^{-1}, \mathrm{CaCO}_{3}-12.50 \%$ and organic matter $-0.17 \%$. Available $\mathrm{N}\left(\mathrm{NH}_{4}-\mathrm{N}\right.$ and $\left.\mathrm{NO}_{3}-\mathrm{N}\right), \mathrm{P}$ and $\mathrm{K}$ were correspondingly $1.68,4.60,0.18$ and $270 \mathrm{mg} \mathrm{kg}^{-1}$. The characteristics of greywater are presented in Table 1 . Electrical conductivity (except under Phragmites karka), $\mathrm{pH}$ and TDS values were within respective prescribed limits of 0.7-3.0 dS m${ }^{-1}, 6-9,3500 \mathrm{mg} \mathrm{L}^{-1}$ as described by Anon., (1985) and NEQS (1997) for irrigation . As for plant available nutrients, $\mathrm{NO}_{3}-\mathrm{N}$ being the major form of $\mathrm{N}$ in treated greywater was under slight to moderate category of 5.0-30 $\mathrm{mg} \mathrm{L}^{-1}$ and $\mathrm{P}$ was below the prescribed limit of 15 $\mathrm{mg} \mathrm{L}^{-1}$. There are no suggested limits for $\mathrm{K}$ in irrigation water.

Pot experiment: Maximum height of maize plants was achieved under greywater applied treatments and minimum under canal water application (Fig. 1a). Among treated greywater treatments, maize plants were taller under Cyperus iria $(50.69 \mathrm{~cm})$, followed by Typha elephantina $(47.74 \mathrm{~cm})$ and Phragmites karka $(46.11 \mathrm{~cm})$ treatments. However, the plant height achieved with untreated greywater $(47.48 \mathrm{~cm})$ was statistically at par with the plant height by Typha elephantina $(47.74 \mathrm{~cm})$ and canal water $(44.73 \mathrm{~cm})$. Plant height was increased by $13.3 \%$ with Cyperus iria, 6.7\% with Typha elephantine and only 3.1\% with Phragmites karka treated greywater treatments over canal water (Table 2). Comparatively, the increase in plant height over untreated greywater was either very small (i.e. Cyperus iria - $6.8 \%$ and Typha elephantina - $0.55 \%$ ) or there was no increase as in case of Phragmites karka (-2.9).

Table 1. Characteristics of greywater used in maize experiment.

\begin{tabular}{|c|c|c|c|c|}
\hline \multirow{2}{*}{ Parameter } & \multirow{2}{*}{ Untreated greywater } & \multicolumn{3}{|c|}{ Treated greywater } \\
\hline & & Cyperusiria & Phragmites karka & Typha elephantina \\
\hline $\left.\mathrm{EC}(\mathrm{dS} \mathrm{m})^{-1}\right)$ & 2.25 & 2.33 & 4.36 & 2.47 \\
\hline $\mathrm{pH}$ & 8.33 & 8.11 & 7.46 & 7.98 \\
\hline $\mathrm{TSS}\left(\mathrm{mg} \mathrm{L}^{-1}\right)$ & 0.03 & 0.07 & 0.27 & 0.06 \\
\hline $\operatorname{TDS}\left(\mathrm{mg} \mathrm{L}^{-1}\right)$ & 1421 & 1442 & 1999 & 1546 \\
\hline $\mathrm{NO}_{3}-\mathrm{N}\left(\mathrm{mg} \mathrm{L}^{-1}\right)$ & 14.6 & 16.8 & 15.6 & 15.2 \\
\hline Soluble P $\left(\mathrm{mg} \mathrm{L}^{-1}\right)$ & 0.702 & 0.562 & 0.800 & 0.393 \\
\hline Soluble K (mg L-1) & 49.13 & 63.07 & 70.33 & 73.37 \\
\hline
\end{tabular}

Table 2. Percent change in plant height, dry matter and nutrient uptake of maize in treatments applied with treated greywater.

\begin{tabular}{|c|c|c|c|c|c|c|c|c|c|c|}
\hline \multirow{3}{*}{ Treated greywater } & \multicolumn{5}{|c|}{ Over canal water } & \multicolumn{5}{|c|}{ Over untreated greywater } \\
\hline & \multirow{2}{*}{ Plant height } & \multirow{2}{*}{ Dry matter } & \multicolumn{3}{|c|}{ Nutrient uptake } & \multirow{2}{*}{ Plant height } & \multirow{2}{*}{ Dry matter } & \multicolumn{3}{|c|}{ Nutrient uptake } \\
\hline & & & $\mathbf{N}$ & $\mathbf{P}$ & $\mathbf{K}$ & & & $\mathbf{N}$ & $\mathbf{P}$ & $\mathbf{K}$ \\
\hline Cyperus iria & 13.3 & 25.1 & 163.7 & 41.7 & 150.6 & 6.8 & 20.6 & 21.72 & 13.3 & 30.5 \\
\hline Phragmites karka & 3.1 & 7.2 & 111.7 & 25.0 & 78.0 & -2.9 & 3.4 & - & - & -7.3 \\
\hline Typha elephantina & 6.7 & 13.7 & 103.3 & 29.2 & 150.6 & 0.55 & 9.6 & -6.2 & 3.3 & 30.5 \\
\hline
\end{tabular}



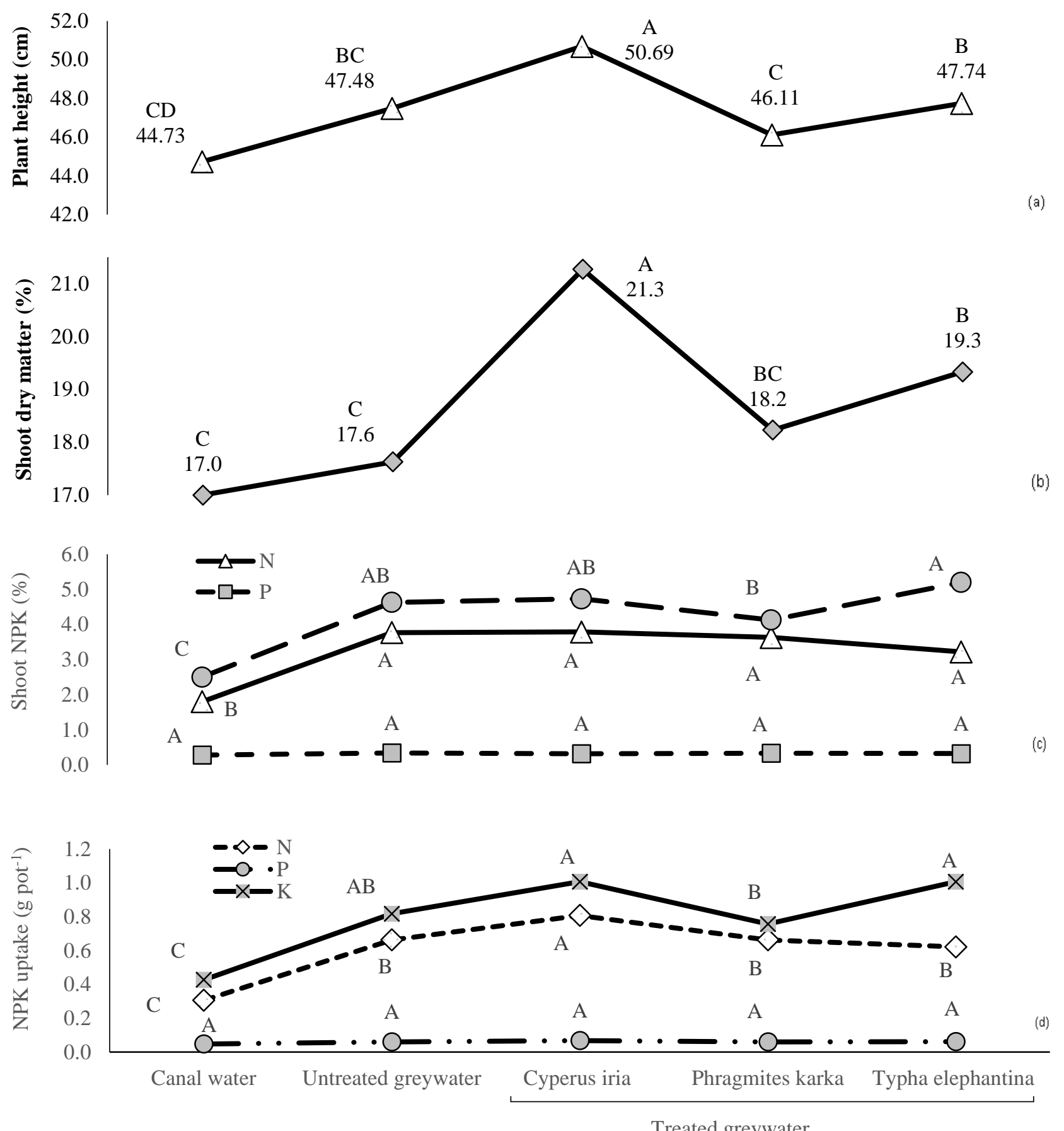

Fig. 1. Effect of greywater on plant height (a), dry matter (b), NPK contents (c) and NPK uptake (d) in maize shoot.

Shoot dry weight followed the same but sharp pattern (Fig. 1b). Dry matter content increased from $17.0 \mathrm{~g} \mathrm{pot}^{-1}$ under canal water treatment to a maximum of $21.3 \mathrm{~g} \mathrm{pot}^{-1}$ under Cyperus iria treatment with significant change. The dry matter content obtained under Typha elephantina $(19.3$ $\mathrm{g} \mathrm{pot}^{-1}$ ) was similar to the one obtained with Phragmites karka $\left(18.2 \mathrm{~g} \mathrm{pot}^{-1}\right)$ and so was the case in canal water (17.0 $\left.\mathrm{g} \mathrm{pot}^{-1}\right)$ and untreated greywater $\left(17.6 \mathrm{~g} \mathrm{pot}^{-1}\right)$ treatments. Shoot dry matter increased by $25.1 \%, 13.7 \%$ and $7.2 \%$ over canal water and $20.6 \%, 9.6 \%$ and $3.4 \%$ correspondingly under Cyperus iria, Typha elephantina and Phragmites karka treatments (Table 2).

The $\mathrm{N}$ content in maize shoots significantly increased from $1.80 \%$ in canal water treatment to a maximum of
$3.79 \%$ under Cyperus iria. However, the $\mathrm{N}$ content of treated and untreated greywater treatments was nonsignificant. Same was true for P under all the treatments including canal water treatment. As for $\mathrm{K}$ content, it increased from $2.50 \%$ under canal water to $5.20 \%$ under Typha elephantine, which was statistically similar to the $\mathrm{K}$ content of Cyperus iria and T. elephantine treatments (Fig. 1c). The nutrient uptake (N, P and K) in maize plants was more or less on similar lines (Fig. 1d). Nitrogen uptake increased by $163.7 \%, 111.7 \%$ and $103.3 \%$ under Cyperus iria, Phragmites karka and Typha elephantine treatments compared to the canal water treatment (Table 2 ). In contrast, the increase in $\mathrm{N}$ content over untreated greywater was only $21.72 \%$ under Cyperus iria. 
Phosphorus uptake increased by $41.7 \%, 25.0 \%$ and $29.2 \%$ over canal water treatment and only by $13.3 \%, 0 \%$ and $3.3 \%$ over untreated greywater correspondingly in Cyperus iria, Phragmites karka and Typha elephantine. While, $\mathrm{K}$ uptake increased to a large extent i.e. $150.6 \%$ under Cyperus iria, 78\% under Phragmites karka and 150.6\% under Typha elephantine over canal water. While, the percent increase in maize uptake by treated greywater (Cyperus iria, Phragmites karka and Typha elephantine) over untreated one, was very small.

\section{Discussion}

Maize plants under all the treatments grew well and did not show any toxicity or unusual symptoms. Highest plant height, shoot dry matter, N, P and K content and relevant shoot uptake were generally recorded in treatments under treated greywater application by Cyperus iria and lowest by canal water irrigation. A comparison over canal water showed a $13 \%$ increase in plant height, $25 \%$ in dry matter, $164-42-151 \%$ in N-P-K maize uptake, in treatments, where the applied greywater was treated under reedbed technology using Cyperus iria. Plant height and shoot dry matter under canal and untreated greywater behaved similarly. Considering the control treatment, the NPK uptake was only $0.31,0.048$ and $0.43 \mathrm{~g} \mathrm{pot}^{-1}$. This further illustrated that NPK uptake of $0.50,0.020$ and $0.58 \mathrm{~g} \mathrm{pot}^{-1}$ was due to greywater application by Cyperus iria. The increase in growth parameters as well as uptake is due to nutrient (i.e. NPK) application. The NPK concentration in maize shoot by Cyperus iria was 3.79-0.32-4.73\%. According to Jones et al., (1991), the N, P and K contents in whole shoot of maize are considered low $(<3.5 \%,<0.3 \%$ and $<2.5 \%)$, sufficient $(3.50-5.00 \%, 0.30-0.50 \%$ and $2.50-4.00 \%)$ and high $(>5.0 \%,>0.5 \%$ and $>4.0 \%)$. With this criteria, the canal water had way "low" contents of N, P and K contents but the treated greywater (Cyperus iria) was "sufficient" in $\mathrm{N}(3.79 \%)$ and $\mathrm{P}(0.32 \%)$ and "high" in $\mathrm{K}(4.73 \%)$ contents. Eliminating the NPK contents due to fertilizer effect $(1.80-0.28-2.50 \%)$ and the nutrients already present in soil, 2.00-0.04-2.24\% N-P-K was contributed by greywater application. This means that about half of the $\mathrm{N}$ and full $\mathrm{K}$ can be substituted from greywater, however, due to low $\mathrm{P}$ content, a full doze of fertilizer $\mathrm{P}$ will be required. Based on the $\mathrm{N}$ contents of treated grey water, Al-Brueck and Lammel (2016) also recommended lower rates of $\mathrm{N}$ fertilizer application to crops. Plant growth and productivity is generally not affected with greywater application, due to its low NPK contents (Finley et al., 2009). The effect on growth and nutrient content or uptake vary widely depending on the greywater quality and soil type. Plant height and shoot dry matter of maize did not show any significant difference among canal and untreated greywater. The same was reported by Pinto et al., (2010) for growth of silverbeet. Their results also confirmed the lower content of $\mathrm{P}$ and to some extent $\mathrm{N}$ in maize plant. The lower contents of P might be due to lesser laundry and dishwashing detergent usage. Increase in $\mathrm{K}$ content and uptake in maize plants in treated greywater over untreated one is evidenced by Al-Hamaiedeh \& Bino (2010) and Travis et al., (2010) for olives and some vegetables.

\section{Conclusion}

This study reported that $2.00-0.04-2.24 \%$ of N-P-K to maize crop came from greywater application. Considering the overall results about $50 \%$ of $\mathrm{N}$ and $100 \%$ of $\mathrm{K}$ requirement of maize crop can be met from the greywater, treated under reed bed technology using Cyperus iria. Depending on the greywater quality and crop requirement, the N-P-K\% will vary. Nonetheless, it contains significant quantities of $\mathrm{N}$ and $\mathrm{K}$ and relatively low $\mathrm{P}$ contents, which can be used as a value added fertilizer in agriculture. It is suggested that soil properties may also be tested after the harvest of crop.

\section{Acknowledgements}

This work is part of DelPHE Project on "Capacity Building for Urban Water Demand Management" in Sindh, funded by UK, through British Council.

\section{References}

Al-Hamaiedeh, H.D. and M. Bino. 2010. Effect of treated grey water reuse in irrigation on soil and plants. Desalination, 256: $115-119$

Anonymous. 1985. Water quality for agriculture. R.S. Ayers and D.W. Westcot, FAO Irrigation and Drainage Paper 29, Rev. 1. FAO, Rome. P. 174.

Anonymous. 2016. Economic Adviser's Wing, Finance Division, Government of Pakistan, Islamabad.

Aslam, M.M., M. Malik and M.A. Baig. 2007. Treatment performance of compost-based and gravel-based vertical flow wetland operation identically refinery wastewater treatment in Pakistan. J. Ecol. Engg., 30(1): 34-42.

AWWA, APHA and WEF. 1998. Standard Methods for Examination of Water and Wastewater $\left(20^{\text {th }} \mathrm{Ed}\right)$. American Public Health Association, Washington.

Brueck, H. and J. Lammel. 2016. Impact of fertilizer N application on the grey water footprint of winter wheat in a NW-European temperate climate. Water, 8(8): 356.

Day, A.D., M.S. Fadyen, J.A., Tucker, T.C. and C.B. Cluff. 1981. Effects of municipal waste water on the yield and quality of cotton. J. Environ. Qual., 10: 47-49.

Eriksson, E., K. Auffarth, A.M. Eilersen, M. Henze and A. Ledin. 2003. Household chemicals and personal care products as sources for xenobiotic organic compounds in grey wastewater. Water SA, 29: 135-146.

Estefan, G., R. Sommer and J. Ryan. 2013. Methods of soil, plant and water analysis. A manual for the West Asia and North Africa region. $3^{\text {rd }}$ Edition, ICARDA, Beirut, Lebanon, p. 68.

Fagan, C.L. 2015. Evaluating the potential for passive greywater irrigation in Northern Ghana. Master's thesis, Michigan Technological University.

Finley, S., S. Barrington and D. Lyew. 2009. Reuse of domestic greywater for the irrigation of food crops. Water Air Soil Pollut., 199: 235-245.

Friedler, E. and M. Hadari. 2006. Economic feasibility of on-site greywater reuse in multi-story buildings. Desalination, 190:221-234.

Hayder, S., H. Haider, O. Nadeem, G. Hussain and S. Zahra. 2015. Proposed model for wastewater treatment in Lahore 
using constructed wetlands. JFET, 22(1): 7-17.

Iram, M., I. Ahmed, Y. Riaz and A. Zehra. 2012. Treatment of wastewater by Lemna minor. Pak. J. Bot., 44(2): 553-557.

Jenssen, P.D. and L. Vråle. 2004. Greywater treatment in combined biofilter/constructed wetlands in cold climate. In: Werner, C. et al. (Eds.). Ecosanclosing the loop. Proc. $2^{\text {nd }}$ Int. Symp. Ecological Sanitation, Lübeck, Apr. 7-11, 2003, GTZ, Germany, p. 875-881.

Jones, Jr. J.B., B. Wolf and H.A. Mills. 1991. Plant analysis handbook. Micro - Macro Publishing Inc., Athens, GA, USA.

Maqbool, M.A., M. Aslami, A. Beshir and B.M. Atta. 2019. Trends in regional and chronological diversity of maize (Zea Mays L.) germplasm in Pakistan. Pak. J. Bot., 51(2): 521533.

Memon, M., H.B. Jatoi, A.M. Narejo, R.B. Mahar, A.K. Ansari and M.I. Bhanger. 2017. Use of aquatic plants for treatment of greywater. Special Issue Pak. J. Bot., 49(SI): 375-381.

Misra, R.K., Patel, J.H. and V.R. Baxi. 2009. Removal of pollutants by tomato plants during reuse of laundry greywater for irrigation. In: International Conference on Food Security and Environmental Sustainability (FSES)Kharagpur, India.

Mustafa, A. 2013. Constructed wetland for wastewater treatment and reuse: A case study of developing country. IJESD, 4(1): 20-24.

Mzini, L.L. and K. Winter. 2015. Analysis of grey-water used for irrigating vegetables and possible effects on soils in the vicinity of Umtata Dam, Eastern Cape. Water $S A$, 41(1): 115120.

NEQS. 1997. Pakistan Environmental Legislation and National Environmental Quality Standards, Government of Sindh, Pakistan.

Oliver, M.M.H. and S.M.I. Hossain. 2016. Effect of greywater irrigation on wheat and mung-bean production in clayeyloam soil. J. Biosci. Agric. Res., 07(02): 659-668.

Pinto, U., B.L. Maheshwari and H.S. Grewal. 2010. Effects of greywater irrigation on plant growth, water use and soil properties. Resour. Conserv. Recycl., 54(6): 429-435.

Rusan, M.J.M., S. Hinnawi and L. Rousan. 2007. Long term effect of wastewater irrigation of forage crops on soil and plant quality parameters. Desalination, 215: 143-152.

Travis, J.M., A. Wiel-Shafran, N. Weisbrod, E. Adar and A. Gross. 2010. Greywater reuse for irrigation effect on soil properties. Sci. Total Environ., 408: 2501-2508.

Zuma, B.M., R. Tandlich, K.J. Whittington-Jones and J.E. Burgess. 2009. Mulch tower treatment system Part I: Overall performance in greywater treatment. Desalination 242(1-3): 38-56.

(Received for publication 11 February 2018) 